\title{
Pathophysiology and Pre-Operative Evaluation of Patients at Risk for Intraoperative Floppy Iris Syndrome (IFIS)
}

\author{
Matthew A. Cantrell ${ }^{1}$, Heather R. Bream-Rouwenhorst ${ }^{1}$, \\ Christopher Watts ${ }^{2}$ and Thomas A. Oetting 2 \\ ${ }^{1}$ University of Iowa College of Pharmacy, Department of Pharmacy \\ Practice and Science, Iowa City, Iowa \\ ${ }^{2}$ University of Iowa Carver College of Medicine, Iowa City, Iowa
}

USA

\section{Introduction}

Intraoperative Floppy Iris Syndrome (IFIS) has received a significant amount of attention and subsequent research since it was first reported in 2005 (Bell et al., 2009; Blouin et al., 2007; Chang \& Campbell, 2005; Chang et al., 2007; Oshika et al., 2007; Srinivasan et al., 2007; Takmaz \& Can, 2007). Current and former uses of alpha-1 adrenergic receptor $\left(a_{1} A R\right)$ antagonists-most notably tamsulosin-appear to be at the highest risk for this surgical complication (Chang \& Campbell, 2005). IFIS is characterized by loss of muscle tone in the iris, thereby preventing mydriasis and involves a triad of pupil constriction, fluttering and billowing of the iris stroma, and propensity for iris prolapse during cataract surgery (Chang \& Campbell, 2005). While $\mathrm{a}_{1} \mathrm{AR}$ antagonists are often used for various urological conditions, they also block $a_{1} A R$ receptors in the iris dilator muscle and may worsen muscle tone and lead to the iris billowing sometimes seen in cataract surgery. Without adequate pupil dilation, IFIS reduces visualization of the surgical field, including the cataract itself. This impairs removal and can lead to other complications including rupture of the posterior capsule, which further increases the risk of other vision-threatening complications of cataract surgery (Schwinn \& Afshari, 2006).

\section{Use of alpha-1 adrenergic receptor (AR) antagonists}

Since there is a significant association between $\mathrm{a}_{1} \mathrm{AR}$ antagonist use and IFIS, a brief review of the indications of $a_{1} A R$ antagonists is necessary to identify the at-risk population. The principal indication is treatment of benign prostatic hyperplasia $(\mathrm{BPH})$. This urological disorder shares risk factors with cataract development, with advanced age being the most significant (Congdon et al., 2004). If left untreated, BPH increases risk for significant complications including acute urinary retention, recurrent urinary tract infections, and urinary incontinence (Crawford et al., 2006). In patients with mild BPH as indicated by an American Urological Association (AUA) scores of 8 or less, pharmacotherapy may not be indicated as lower urinary tract symptoms (LUTS) often improve spontaneously. Identifying 
suitable candidates for this strategy, often called "watchful waiting," is critical to reduce unnecessary exposure to $\mathrm{a}_{1} \mathrm{AR}$ therapy and is recommended by the AUA to invariably reduce risk for IFIS (American Urological Association [AUA], 2010). Pharmacotherapy for $\mathrm{BPH}$ is indicated in patients with moderate to severe disease and includes the 5-alpha reductase inhibitors (5ARI) and $a_{1} A R$ receptor antagonists. The 5ARI finasteride and dutasteride inhibit conversion of testosterone to dihydrotesterone, thereby shrinking the prostate; the $\mathrm{a}_{1} \mathrm{AR}$ antagonists reduce bladder outlet obstruction by relaxing prostatic smooth muscle tissue surrounding the urethra. The currently available agents include terazosin, doxazosin, alfuzosin, tamsulosin, and silodosin. They have comparable effects in symptom reduction (Djavan et al., 2004; Marks et al., 2009). While terazosin and doxazosin were originally developed for treatment of hypertension, their use for this indication has waned largely due to publication of the ALLHAT trial which demonstrated a higher incidence of hospitalization for congestive heart failure (CHF) in the doxazosin arm relative to chorthalidone (ALLHAT, 2000). Subsequent "uroselective" agents that target the $\mathrm{a}_{1 \mathrm{~A}} \mathrm{AR}$ have been developed including tamsulosin, and most recently silodosin. (Package insert Flomax 2007; Package insert Rapaflo 2008). Alfuzosin's improved tolerability is largely attributable to its extended-release formulation, which prevents peaks in serum concentrations (Roehrborn et al., 2000)

Aside from the robust data demonstrating benefit in men with $\mathrm{BPH}$, these agents have an emerging role in other areas of urology including facilitating the passage of urinary caliculi, as an adjunctive treatment for chronic prostatitis, following ureteral stent placement, and also improving symptoms of overactive bladder in select patients (Anothaisintawee et al., 2011; Kaplan et al., 2006; Navanimitkul \& Lojanapiwat, 2010; Singh et al., 2007). Use of a $a_{1} A R$ is limited outside the urological arena; however, some patients are undoubtedly still taking them for treatment refractory hypertension. Finally, data suggests that prazosin-an agent no longer endorsed by the AUA for treatment of BPH due to its unfavorable adverse effect and pharmacokinetic profile-has been shown to be effective in reducing nightmares secondary to post-traumatic stress disorder (PTSD) (Dierks et al., 2007; Raskind et al., 2003). It is imperative that ophthalmologists recognize the various indications for $\mathrm{a}_{1} \mathrm{AR}$ therapy to identify those at risk for IFIS. While men are at higher risk based on their respective use of $\mathrm{a}_{1} \mathrm{AR}$ for treatment of $\mathrm{BPH}$, physicians should recognize that that some women may be taking these agents for other indications as well.

\section{Pathophysiology of IFIS}

The $a_{1} A R s$ are G-protein coupled receptors and subdivided into $a_{1 A} A R, a_{1 B} A R$, and $a_{1 D} A R$ subtypes. Stimulation of $\mathrm{a}_{1} \mathrm{AR}$ elicits contraction of cardiac and most innervated vascular smooth muscle throughout the body (Biaggioni \& Robertson, 2009). Like the iris dilator muscle, the prostate contains a significant volume of smooth muscle rich in ARs. BPH and its associated LUTS involve the prostate, urethra, bladder, and spinal cord. The $\mathrm{a}_{1 \mathrm{~A}}$ and $\mathrm{a}_{1 \mathrm{D}} \mathrm{AR}$ predominate in these organs, but $\mathrm{a}_{1 \mathrm{~B}} \mathrm{AR}$ are also present. As the prostate grows in $\mathrm{BPH}$, there is upregulation of $\mathrm{a}_{1} \mathrm{AR}$ expression, with studies demonstrating that expression of $a_{1 A} A R s$ increases up to 9-fold and $a_{1 D} A R s$ by 3-fold. This upregulation, especially of $\mathrm{a}_{1 \mathrm{~A}} \mathrm{AR}$, is thought to be responsible for the disproportionate increase in smooth muscle contraction and worsening of LUTS in patients with BPH (Thiyagarajan, 2002). Therefore, $\mathrm{a}_{1} \mathrm{AR}$ antagonists are useful in ameliorating symptoms associated with $\mathrm{BPH}$ by decreasing prostatic urethral resistance although this blockade may influence iris behavior (Shapiro et 
al., 1992). Specifically, use of $\mathrm{a}_{1} \mathrm{AR}$ antagonists for $\mathrm{BPH}$ relieves straining and hesitancy, improves bladder emptying, and increases the force of the urinary stream.

Commonly used second-generation $\mathrm{a}_{1} \mathrm{AR}$ antagonists include doxazosin and terazosin, although patient tolerability to these agents is variable, with the most vexing clinical problems being orthostatic hypotension and dizziness (McNaughton-Collins \& Barry, 2005). Frail geriatric patients often suffer from gait problems, and the addition of a medication that could increase the potential of a fall is undesirable. The increased $a_{1 A} A R$ selectivity of the third-generation "uroselective" agents tamsulosin and silodosin is postulated to provide additional relief of LUTS in patients with BPH without increasing the rate of serious adverse cardiovascular effects due to systemic aAR antagonism. (Cantrell et al., 2008; Cantrell et al., 2010)

$\mathrm{a}_{1} \mathrm{AR}$ antagonists not only therapeutically inhibit prostatic $\mathrm{a}_{1} \mathrm{AR}$ but may also selectively antagonize these receptors in the iris dilator muscle. In the iris, $\mathrm{a}_{1 \mathrm{~A}} \mathrm{AR}$ mediate iris dilator smooth muscle contraction whereas iris arteriolar contraction is mediated via $\mathrm{a}_{1 \mathrm{~B}} \mathrm{AR}$. Blockade of this muscle's $\mathrm{a}_{1} \mathrm{AR}$ is hypothesized to lead to poor muscle tone and the subsequent iris billowing sometimes seen in cataract surgery (Schwinn \& Afshari, 2006). Figure 1 illustrates the clinical dilemma of IFIS and the subsequent potential for surgical complications.

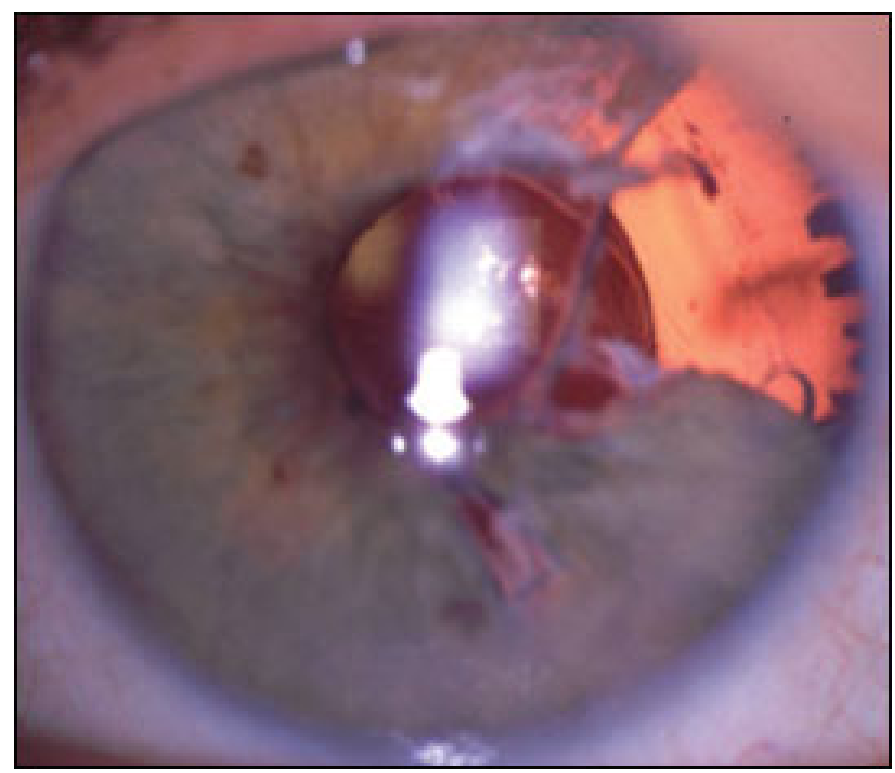

Adapted or Reprinted with permission from 'Editorials: Floppy Iris Syndrome: Why BPH

Treatment Can Complicate Cataract Surgery,' June 15, 2009, American Family Physician. Copyright (C) 2009 American Academy of Family Physicians. All Rights Reserved

Fig. 1. Iris damage following cataract surgery in a patient taking tamsulosin

Although Chang and Campbell first associated IFIS with tamsulosin in 2005, other available $a_{1} A R$ antagonists were subsequently linked to IFIS as well (Dhingra et al., 2007; Herd, 2007; Package insert Rapaflo, 2008; Settas \& Fitt, 2006; Venkatesh et al., 2007). 
Potentially, the high $\mathrm{a}_{1 \mathrm{~A}} \mathrm{AR}$-specific antagonism of tamsulosin made the association easier to identify. In rabbits, tamsulosin was more effective than the non-specific $\mathrm{a}_{1} \mathrm{AR}$ antagonist alfuzosin at blocking adrenergic-mediated iris dilator contraction (Palea et al., 2008). Interestingly, functional studies assessing the affinity of different ARs as measured by $\mathrm{pKi}$ (negative logarithm of the equilibrium dissociation constant) reflect higher affinity of silodosin for $\mathrm{a}_{1 \mathrm{~A}} \mathrm{AR}$ compared to older agents; when compared to other currently available $a_{1} A R$ antagonists, silodosin is 1400 times more specific in terms of $a_{1 A} A R$ versus $\mathrm{a}_{1 \mathrm{~B}} \mathrm{AR}$ binding than doxazosin and terazosin and 40 times greater compared to tamsulosin (Thiyagarajan, 2002). It remains to be seen if silodosin has a greater likelihood to cause IFIS than the other available agents.

In a rabbit study, Palea et al. suggested an additional unrecognized receptor may be involved in contraction of the iris dilator muscle as $a_{1} A R$ blockade with tamsulosin and alfuzosin was less prominent in the iris than the prostate (Palea et al., 2008). While $\alpha_{1 \mathrm{~A}} \mathrm{AR}$ are commonly reported as the predominant subtype in the iris dilator muscle in animal studies (Suzuki et al., 2002; Yu \& Koss, 2003), Flach pointed out that assuming $\mathrm{a}_{1 \mathrm{~A}} \mathrm{AR}$ predominate in the human iris dilator muscle based off rabbit studies may be misleading (Flach, 2009). Nevertheless, human immunohistochemical analysis has shown $\mathrm{a}_{1 \mathrm{~A}} \mathrm{ARs}$ to localize to iris arteriolar muscularis and the iris dilator muscle (Panagis et al., 2010).

\section{Risk factors for IFIS}

The most comprehensive assessment of risk factors for IFIS was recently published. This meta-analysis included seventeen studies totaling 17,588 eyes (Chatziralli \& Sergentanis, 2010). It assessed current use of $a_{1} A R$ antagonist therapy as well as the effect of co-variates hypertension and diabetes. Current tamsulosin use was associated with the highest risk among the groups studied. Current use of alfuzosin and terazosin was associated with lower risk relative to tamsulosin but remained statistically significant. The pooled analysis of doxazosin did not reach statistical significance; however, the authors cautioned that more studies are needed to gain statistical power. Of the covariates tested, only current hypertension increased risk for IFIS. Despite mixed results in various studies, diabetes did not emerge as a significant risk factor for IFIS. The authors concluded that, consistent with previous reports, it appears that tamsulosin use is associated with the highest risk of IFIS relative to other agents.

There is limited information regarding doxazosin, prazosin and the most recently approved agent silodosin. However, as the latter's pharmacology most resembles tamsulosin and because of its high affinity for the $a_{1 A} A R$, it should be presumed that there is an inherent risk with silodosin until data suggests otherwise. A complete list of medications medications associated with IFIS is described in Table 1.

\section{Literature review}

IFIS was originally reported in a retrospective study of 511 patients who underwent cataract surgery (Chang \& Campbell, 2005). Twenty-seven patients (5.3\%) totaling 40 eyes had preoperative exposure to $\mathrm{a}_{1} \mathrm{AR}$ antagonists. Ten of sixteen $(62.5 \%)$ patients who received tamsulosin prior to surgery developed IFIS. In the remaining eleven patients on other $\mathrm{a}_{1} \mathrm{AR}$ antagonists, there were no documented cases of IFIS. However, the authors 
reported that all twenty-seven patients had "poor or moderately poor dilation." A complete list of studies assessing incidence of IFIS as well as studies assessing rates of surgical complications in patients prescribed $a_{1} A R$ antagonists are described in Table 2

$\begin{array}{ll}\text { Alpha-1 adrenergic receptor (AR) antagonists } & \text { Miscellaneous } \\ \text { tamsulosin } & \text { finasteride } \\ \text { terazosin } & \text { saw palmetto } \\ \text { doxazosin } & \text { donepezil } \\ \text { alfuzosin } & \text { risperidone } \\ \text { prazosin } & \text { chlorpromazine } \\ \text { silodosin } & \end{array}$

Table 1. Medications associated with IFIS

In a prospective analysis of 900 consecutive cataract surgeries among 741 patients, IFIS was observed in sixteen patients (2.2\%), fourteen of whom had documented concomitant use of tamsulosin (Chang \& Campbell, 2005). In the two remaining patients, one had discontinued tamsulosin three years prior to surgery, and one had no history of tamsulosin exposure. Furthermore, IFIS was reported in both eyes of the five patients taking tamsulosin that required bilateral cataract surgery.

Despite the authors' initial identification of a potentially serious complication of cataract surgery, reported limitations of the study include lack of covariate data and the modest reported use of $\mathrm{a}_{1} \mathrm{AR}$ antagonists at 1.9\% (Chang \& Campbell, 2005; Schwinn \& Afshari, 2006). As stated above, patients with BPH may not always require pharmacologic treatment, specifically in patients with mild American Urological Association (AUA) symptom scores (AUA, 2010). This may partially explain the relatively low percentage of tamsulosin use in a population with a historically high prevalence of BPH.

In a recent study assessing incidence, IFIS was reported to be $1.6 \%$ among 774 patients (Takmaz \& Can, 2007). IFIS was documented in 14 of 18 patients (77.8\%) taking tamsulosin, and consistent with the original report by Chang and Campbell, tamsulosin use overall was observed in $2.2 \%$ of patients. Duration of tamsulosin use-although increased among patients diagnosed with IFIS - was not statistically significant relative to those without IFIS.

A recent study directly compared the incidence of IFIS attributable to tamsulosin with an active comparator group. (Blouin et al., 2007). In this retrospective study of 64 men totaling 92 eyes, there was an increased risk of IFIS in patients exposed to tamsulosin $(86.4 \%)$ when compared to alfuzosin (15.4\%). The adjusted odds ratio for IFIS in patients taking tamsulosin when compared to alfuzosin was 32.15 (95\% confidence interval, 2.74-377.41). Furthermore, a five-fold increase in surgical complication rates was observed in patients diagnosed with IFIS, highlighting its clinical significance. 


\begin{tabular}{|c|c|c|c|c|c|c|c|}
\hline Reference & Design & Objective & Population & $\begin{array}{l}\text { Overall } \\
\text { Prevalence } \\
\text { or } \\
\text { Incidence } \\
\text { of IFIS (\%) }\end{array}$ & $\begin{array}{l}\text { Exposure } \\
\text { to Systemic } \\
\mathrm{a}_{1} \mathrm{AR} \\
\text { Antagonist } \\
(\%)\end{array}$ & $\begin{array}{l}\text { Prevalence or } \\
\text { Incidence of } \\
\text { IFIS in } \\
\text { Tamsulosin- } \\
\text { Treated } \\
\text { Patients (\%) } \\
\end{array}$ & Comments \\
\hline \multirow{2}{*}{$\begin{array}{l}\text { Chang \& } \\
\text { Campbell, } \\
2005\end{array}$} & $\begin{array}{l}\text { Clinical } \\
\text { study 1: } \\
\text { retrospectiv } \\
\text { e chart } \\
\text { review }\end{array}$ & \multirow{2}{*}{$\begin{array}{l}\text { Assess } \\
\text { incidence } \\
\text { and possible } \\
\text { causative } \\
\text { factors of } \\
\text { IFIS }\end{array}$} & $\mid \begin{array}{l}511 \\
\text { patients; } \\
706 \text { eyes } \\
-\end{array}$ & $\begin{array}{l}10 / 511 \\
\text { patients } \\
(2.0)\end{array}$ & $\begin{array}{l}27 / 511 \\
\text { patients } \\
(5.3)\end{array}$ & $\begin{array}{l}10 / 16 \\
\text { patients (62.5) }\end{array}$ & \\
\hline & $\begin{array}{l}\text { Clinical } \\
\text { study 2: } \\
\text { prospective } \\
\text { case series }\end{array}$ & & $\begin{array}{l}741 \\
\text { patients; } \\
900 \text { eyes }\end{array}$ & $\begin{array}{l}16 / 741 \\
\text { patients } \\
(2.2)\end{array}$ & $\begin{array}{l}\text { Not } \\
\text { available }\end{array}$ & $\begin{array}{l}15 / 16 \\
\text { patients (93.8) }\end{array}$ & \\
\hline $\begin{array}{l}\text { Chang } \\
\text { et al., } 2007\end{array}$ & $\begin{array}{l}\text { Prospective, } \\
\text { multicenter, } \\
\text { nonrandomiz } \\
\text { ed } \\
\text { observational } \\
\text { series }\end{array}$ & \begin{tabular}{|l|} 
Evaluate \\
surgical \\
outcomes \\
and rate of \\
complication \\
s when \\
ophthalmolo \\
gist knew \\
patient was \\
taking \\
tamsulosin \\
\end{tabular} & $\begin{array}{l}135 \\
\text { patients; } \\
167 \text { eyes }\end{array}$ & $\begin{array}{l}\text { No IFIS: } \\
10 \% \text { of eyes; } \\
\text { mild: } 17 \% \\
\text { of eyes; } \\
\text { moderate- } \\
\text { severe: } \\
73 \% \text { of } \\
\text { eyes }\end{array}$ & $\begin{array}{l}135 / 135 \\
\text { patients } \\
(100)\end{array}$ & $\begin{array}{l}150 / 167 \text { eyes } \\
(89.8)\end{array}$ & \\
\hline $\begin{array}{l}\text { Blouin } \\
\text { et al., } 2007\end{array}$ & $\begin{array}{l}\text { Retrospectiv } \\
\text { e chart } \\
\text { review }\end{array}$ & \begin{tabular}{|l|} 
Compare \\
IFIS risk in \\
men taking \\
tamsulosin \\
vs. alfuzosin
\end{tabular} & $\begin{array}{l}332 \\
\text { patients; } \\
461 \text { eyes }\end{array}$ & $\begin{array}{l}61 / 461 \\
\text { eyes (13.2) }\end{array}$ & $\begin{array}{l}64 / 332 \\
\text { patients } \\
(19.3)\end{array}$ & $\begin{array}{l}19 / 22 \\
\text { patients (86.4) }\end{array}$ & $\begin{array}{l}\text { IFIS in } 2 / 13 \\
(15.4 \%) \text { patients } \\
\text { exposed to } \\
\text { alfuzosin }\end{array}$ \\
\hline $\begin{array}{l}\text { Srinivasan } \\
\text { et al., } 2007\end{array}$ & $\begin{array}{l}\text { Retrospectiv } \\
\text { e chart } \\
\text { review }\end{array}$ & \begin{tabular}{|l|} 
Determine \\
occurrence of \\
IFIS in those \\
exposed to \\
systemic \\
$\mathrm{a}_{1} \mathrm{AR}$ \\
antagonists \\
\end{tabular} & $\mid \begin{array}{l}1298 \\
\text { patients; } \\
1612 \text { eyes }\end{array}$ & $\begin{array}{l}13 / 1298 \\
\text { patients } \\
(1.0)\end{array}$ & $\begin{array}{l}65 / 1298 \\
\text { patients } \\
(5.0)\end{array}$ & $\begin{array}{l}10 / 13 \\
\text { patients (76.9) }\end{array}$ & $\begin{array}{l}\text { IFIS in } 2 \text { patients } \\
\text { exposed to } \\
\text { terazosin and } 1 \\
\text { patient exposed to } \\
\text { doxazosin }\end{array}$ \\
\hline $\begin{array}{l}\text { Takmaz \& } \\
\text { Can, } 2007\end{array}$ & $\begin{array}{l}\text { Prospective, } \\
\text { nonrandomi } \\
\text { zed } \\
\text { observation } \\
\text { al study }\end{array}$ & \begin{tabular}{|l|} 
Evaluate \\
complication \\
rates, effect \\
of \\
intracameral \\
adrenaline, \\
and \\
incidence of \\
IFIS in \\
patients \\
taking \\
tamsulosin \\
\end{tabular} & $\begin{array}{l}774 \\
\text { patients; } \\
858 \text { eyes }\end{array}$ & $\begin{array}{l}16 / 858 \\
\text { eyes (1.9) }\end{array}$ & $\begin{array}{l}24 / 858 \\
\text { eyes (2.8) }\end{array}$ & $\begin{array}{l}14 / 18 \text { eyes } \\
(77.8)\end{array}$ & $\begin{array}{l}\text { IFIS in } 1 \text { of } 4 \text { eyes } \\
\text { exposed to } \\
\text { terazosin and } 1 \text { of } 2 \\
\text { eyes exposed to } \\
\text { alfuzosin }\end{array}$ \\
\hline $\begin{array}{l}\text { Oshika } \\
\text { et al., } 2007\end{array}$ & $\begin{array}{l}\text { Prospective, } \\
\text { intervention } \\
\text { al case series }\end{array}$ & $\begin{array}{l}\text { Compare } \\
\text { incidence of } \\
\text { IFIS with } \\
\text { topical vs. } \\
\text { systemic } \\
\mathrm{a}_{1} \text { AR } \\
\text { antagonists } \\
\end{array}$ & $\begin{array}{l}1968 \\
\text { patients; } \\
2643 \text { eyes }\end{array}$ & $\begin{array}{l}29 / 2643 \\
\text { eyes }(1.1)\end{array}$ & $\begin{array}{l}134 / 2643 \\
\text { eyes (5.1) }\end{array}$ & $\begin{array}{l}25 / 58 \text { eyes } \\
(43.1)\end{array}$ & $\begin{array}{l}\text { No IFIS in } \\
\text { bunazosin (topical } \\
\text { a1AR antagonist } \\
\text { which is not } \\
\text { a1AAR-specific) } \\
\text { group }\end{array}$ \\
\hline
\end{tabular}




\begin{tabular}{|c|c|c|c|c|c|c|c|}
\hline Reference & Design & Objective & Population & $\begin{array}{l}\text { Overall } \\
\text { Prevalence } \\
\text { or } \\
\text { Incidence } \\
\text { of IFIS (\%) }\end{array}$ & $\begin{array}{l}\text { Exposure } \\
\text { to Systemic } \\
\alpha_{1} \mathrm{AR} \\
\text { Antagonist } \\
(\%)\end{array}$ & $\begin{array}{l}\text { Prevalence or } \\
\text { Incidence of } \\
\text { IFIS in } \\
\text { Tamsulosin- } \\
\text { Treated } \\
\text { Patients }(\%) \\
\end{array}$ & Comments \\
\hline $\begin{array}{l}\text { Amin et al. } \\
(2008)\end{array}$ & $\begin{array}{l}\text { Prospective } \\
\text { observation } \\
\text { al study }\end{array}$ & $\begin{array}{l}\text { Assess } \\
\text { incidence of } \\
\text { IFIS } \\
\text { associated } \\
\text { with } \\
\text { tamsulosin } \\
\end{array}$ & $\mid \begin{array}{l}1267 \\
\text { patients; } \\
1462 \text { eyes }\end{array}$ & $\begin{array}{l}\text { Not } \\
\text { available }\end{array}$ & $\begin{array}{l}\text { Not } \\
\text { available }\end{array}$ & $\begin{array}{l}13 / 23 \text { eyes } \\
(56.5)\end{array}$ & \\
\hline $\begin{array}{l}\text { Keklikci } \\
\text { et al. (2009) }\end{array}$ & $\begin{array}{l}\text { Prospective, } \\
\text { nonrandomi } \\
\text { zed } \\
\text { observation } \\
\text { al study }\end{array}$ & $\begin{array}{l}\text { Assess } \\
\text { incidence of } \\
\text { IFIS } \\
\text { associated } \\
\text { with } \\
\text { tamsulosin }\end{array}$ & $\begin{array}{l}579 \\
\text { patients; } \\
594 \text { eyes }\end{array}$ & $\begin{array}{l}15 / 579 \\
\text { eyes }(2.6)\end{array}$ & $\begin{array}{l}\text { Not } \\
\text { available }\end{array}$ & $\begin{array}{l}12 / 23 \\
\text { patients (52.2) }\end{array} \mid$ & \\
\hline $\begin{array}{l}\text { Chen } \\
\text { et al. (2010) }\end{array}$ & $\begin{array}{l}\text { Retrospectiv } \\
\text { e cohort } \\
\text { study }\end{array}$ & $\begin{array}{l}\text { Determine } \\
\text { incidence of } \\
\text { IFIS in } \\
\text { patients } \\
\text { taking } \\
\text { tamsulosin, } \\
\text { effect of } \\
\text { prophylactic } \\
\text { measures } \\
\end{array}$ & 1163 eyes & $\begin{array}{l}\text { Not } \\
\text { available }\end{array}$ & $\begin{array}{l}\text { Not } \\
\text { available }\end{array}$ & $\begin{array}{l}24 / 81 \text { eyes } \\
(29.6)\end{array}$ & \\
\hline $\begin{array}{l}\text { Horvath \& } \\
\text { Vultur } \\
(2011)\end{array}$ & $\begin{array}{l}\text { Prospective, } \\
\text { nonrandomi } \\
\text { zed } \\
\text { observation } \\
\text { al study }\end{array}$ & $\begin{array}{l}\text { Report } \\
\text { incidence, } \\
\text { etiology and } \\
\text { management } \\
\text { of IFIS }\end{array}$ & $\begin{array}{l}438 \\
\text { patients; } \\
439 \text { eyes }\end{array}$ & $\begin{array}{l}37 / 439 \\
\text { eyes }(8.4)^{\mathrm{a}}\end{array}$ & $\begin{array}{l}15 / 439 \\
\text { eyes (3.4) }\end{array}$ & Not available & $\begin{array}{l}\text { Incidence of IFIS in } \\
\text { patients treated } \\
\mathrm{w} / \mathrm{a}_{1} \mathrm{AR}=86.7 \%\end{array}$ \\
\hline
\end{tabular}

a Includes patients that experienced an IFI-like syndrome

Table 2. Incidence and prevalence of IFIS in selected studies

Following the original report suggesting a stronger link between tamsulosin and IFIS relative to other $\mathrm{a}_{1} \mathrm{AR}$ antagonists, subsequent case reports of IFIS have been published in men taking alfuzosin, doxazosin, and terazosin (Dhingra et al., 2007; Herd, 2007; Settas \& Fitt, 2006; Venkatesh et al., 2007).

Aside from IFIS, $a_{1} A R$ antagonist therapy prior to cataract surgery has been shown to predispose patients to complications following cataract surgery (Bell et al., 2009). A nested case control study examined health care records of 96,128 Canadian men aged 66 years or older who had undergone cataract surgery over a 5 year period. Post-operative complications that were examined included retinal detachment, lost lens or lens fragment, or endophalmitis. Overall, $3.7 \%$ had a history of exposure to tamsulosin, and $7.7 \%$ had recently taken other alpha blockers. Cases - that is men with a history of complications were matched to control patients. The authors identified complications in 280 patients $(0.3 \%)$. These cases were randomly matched to control patients based on age, surgeon, and year of procedure. Complications were more common among current users of tamsulosin. This risk was not significantly increased with exposure to other $\mathrm{a}_{1} \mathrm{AR}$ antagonists or to previous exposure to tamsulosin or other $\mathrm{a}_{1} \mathrm{AR}$ antagonists. However, tamsulosin use within 14 days of cataract surgery increased the risk for complications. 
Currently, risk of IFIS has only been associated with systemic use of $\mathrm{a}_{1} \mathrm{AR}$ antagonists. In a study comparing the incidence of IFIS between topical and systemic administration, no cases were observed in patients taking bunazosin, a topical, non-selective, $\mathrm{a}_{1} \mathrm{AR}$ antagonist which is not currently available in the United States (Oshika et al., 2007). In the tamsulosin comparator group, the incidence of IFIS was $1.1 \%$. Notably, results may have differed had the topical agent used also been specific for the $\mathrm{a}_{1 \mathrm{~A}} \mathrm{AR}$ subtype.

In response to multiple reports of an increased risk of IFIS, the package labeling of tamsulosin and other $\mathrm{a}_{1} \mathrm{AR}$ antagonists has been updated to reflect this potential risk. The labeling further acknowledges that benefits of stopping an $a_{1} A R$ antagonist prior to cataract surgery remains unknown (Package insert Flomax, 2007).

The 5ARI finasteride and the extract of saw palmetto (Serona repens) a type of palm plant utilized largely as alternative medicine for treatment of BPH have been linked to IFIS (Issa \& Dagres, 2007; Yeu \& Grostern, 2007). The patients in the aforementioned cases were specifically stated to not have received $a_{1} A R$ antagonists prior to cataract surgery; however, the possibility exists that the patients may have received an unrecognized $a_{1} A R$ antagonist either currently or in the past. No mechanism for how these agents may cause IFIS has been postulated, and the effect of how 5ARIs interact with the iris has not been studied. While confounders common to patients taking either $5 \mathrm{ARIs}$ or $\mathrm{a}_{1} \mathrm{AR}$ antagonists such as increased age or male gender cannot be ruled out, certainly the strongest evidence of a link between medication and IFIS is with $\mathrm{a}_{1} \mathrm{AR}$ antagonists and not 5ARIs.

Aside from $\mathrm{a}_{1} \mathrm{AR}$ antagonists, IFIS has been associated with other medications as well. Lending credence to the theory that $\mathrm{a}_{1} \mathrm{AR}$ antagonism is heavily responsible for IFIS, the antipsychotics chlorpromazine and risperidone, both mild $\mathrm{a}_{1} \mathrm{AR}$ antagonists, have been linked to IFIS in patients not previously haven received conventional $a_{1}$-AR antagonists (Ford et al., 2011; Unal et al., 2007). Labetalol, a dual $\alpha_{1}$ - and $\beta$-AR antagonist, has also been associated with IFIS (Calotti \& Steen, 2007).

One case of acetylcholinesterase-inhibitor-associated IFIS with donepezil has been reported. The authors hypothesized that through enhancement of cholinergic activity on the pupil sphincter, the pharmacological effect of the preoperative dilating drops was overcome (Papadopoulos \& Bachariou, 2007). The patient reportedly had never received an $a_{1} A R$ antagonist. However, a complete medication list was not documented in the case, and receipt of other $\mathrm{a}_{1} \mathrm{AR}$ antagonists cannot be ruled out.

\section{Pre-operative evaluation}

The relationship of $\mathrm{a}_{1} \mathrm{AR}$ antagonists to IFIS has changed the preoperative process for cataract surgeons. The pre-operative evaluation is particularly difficult as there is currently no reliable way to predict which patients will demonstrate IFIS. Furthermore as IFIS can present unilaterally the absence in one eye does not preclude the other eye from demonstrating features of IFIS in a subsequent surgery (Issa et al., 2008). During the pre operative visit, there are a number of questions and observations which may highlight for the surgeon any patients at potential risk for IFIS.

Most importantly is to ask all patients about current or former use of $\mathrm{a}_{1} \mathrm{AR}$ antagonists. Simply reviewing the current medication list is not sufficient. Many patients are unable to recall specific medication names or classes they are currently taking, much less a medication they took previously and since discontinued. Because of this, often times asking a patient or an accompanying family member if they have ever been treated for an enlarged prostate or 
for difficulty emptying their bladder will help elicit a more accurate history. If a patient does have a history of $a_{1} A R$ antagonists it is also important to counsel them on the associated increased risk of IFIS and subsequent risk of complications postoperatively.

The most reliable preoperative predictive feature of IFIS in a patient with a history of $\mathrm{a}_{1} \mathrm{AR}$ antagonists is poor pupillary dilation (Oetting, 2009). This can and should be noted during the office pre-operative cataract surgery evaluation, and not just on the day of surgery. When the pupil does not dilate well, the surgeon should be wary of IFIS during surgery. Although poor dilation can also be a harbinger of other intra ocular conditions such as pseudoexfoliation and trauma, recognition will help the surgeon prepare for and adapt intra operative management strategies for all possible complications (Altan-Yaycioglu. et al., 2007).

\section{Conclusion}

Recognizing patients at risk for IFIS is paramount to management. Without adequate preparation and management IFIS and subsequent postoperative complications are possible. A detailed pre-operative evaluation including recognizing those at risk for IFIS will ensure the best outcome.

\section{References}

Altan-Yaycioglu, R. Yaycioglu, \& O. Gul, U. et al. (2007). The effects of two systemic alpha-1 adrenergic blockers on pupil diameter: a prospective single blind study. Arch Pharmacol, (2007). Vol. 375, No.3 (May 2007), pp. 199-203.

Amin, K.; Fong, K. \& Horgan, SE. (2008). Incidence of intra-operative floppy iris syndrome in a U.K. district general hospital and implications for future workload. Surgeon. Vol. 6, No. 4, (August 2008), pp. 207-209.

Anothaisintawee, T.; Attia, J. \& Nickel, JC. et al. (2011). Management of chronic prostatitis/chronic pelvic pain syndrome: a systematic review and network metaanalysis. JAMA, Vol.305, No.1, (January 2011), pp. 78-86.

Bell, CM.; Hatch, WV. \& Fischer, HD. et al. (2009). Association between tamsulosin and serious ophthalmic adverse events in older men following cataract surgery. JAMA, Vol.301, No.19, (May 2009), pp. 1991-1996.

Biaggioni, I., \& Robertson, D. (2009). Adrenoceptor Agonists \& Sympathomimetic Drug, In: Basic \& Clinical Pharmacology, Katzung, BG., Masters, SB. \& Trevor, AJ. The McGraw-Hill Companies, Inc., Retrieved from http:/ / www.accesspharmacy.com.proxy.lib.uiowa.edu/content.aspx?aid=4520412

Blouin, MC.; Blouin, J. \& Perreault, S. et al. (2007). Intraoperative floppy-iris syndrome associated with alpha1 adrenoreceptors: comparison of tamsulosin and alfuzosin. J Cataract Refract Surg, Vol.33, No.7, (July 2007),pp. 1227-1234.

Calotti, F. \& Steen, D. (2007). Labetalol causing intraoperative floppy-iris syndrome. J Cataract Refract Surg, Vol.33,No.1, (January 2007), pp. 170-171.

Cantrell, MA.; Bream-Rouwenhorst, HR. \& Steffensmeier, A. et al. (2008). Intraoperative

floppy iris syndrome associated with a1-adrenergic receptor antagonists. Ann Pharmacother, Vol. 42, No. 4, (April 2008), pp. 558-563.

Cantrell, MA.; Bream-Rouwenhorst, HR. \& Hemerson, P. et al. (2010). Silodosin for benign prostatic hyperplasia. Ann Pharmacother, Vol.44, No.2, (February 2010), pp. 302-310. 
Chang, DF. \& Campbell, JR. (2005). Intraoperative floppy iris syndrome associated with tamsulosin. J Cataract Refract Surg, Vol.31, No.4, (April 2005), pp. 664-673.

Chang, DF.; Osher, RH. \& Wang, L. et al. (2007). Prospective multicenter evaluation of cataract surgery in patients taking tamsulosin (Flomax). Ophthalmology. Vol.114, No.5, (May 2007), pp. 957-964.

Chatziralli, IP. \& Sergentanis, TN. (2010). Risk Factors for Intraoperative Floppy Iris Syndrome: A Meta-Analysis. Ophthalmology, (December 2010). [Epub ahead of print].

Chen, AA.; Kelly, JP. \& Bhandari, A. et al. (2010). Pharmacologic prophylaxis and risk factors for intraoperative floppy-iris syndrome in phacoemulsification performed by resident physicians. J Cataract Refract Surg. Vol. 36, No. 6, (June 2010), pp. 898905.

Congdon, N.; Vingerling, JR. \& Klein, BE. et al. (2004). Prevalence of cataract and pseudophakia/aphakia among adults in the United States. Arch Ophthalmol, Vol.122, No.4, (April 2004), pp. 487-494.

Crawford, ED.; Wilson, SS. \& McConnell, JD. et al. (2006). Baseline factors as predictors of clinical progression of benign prostatic hyperplasia in men treated with placebo. $J$ Urol, Vol.175, No.4, (April 2006), pp. 1422-1426; discussion 1426-1427.

Dhingra, N.; Rajkumar, KN. \& Kumar, V. (2007). Intraoperative floppy iris syndrome with doxazosin. Eye, Vol.21,No.5, (May 2007), pp. 678-679.

Dierks, MR.; Jordan, JK. \& Sheehan, AH. (2007). Prazosin treatment of nightmares related to posttraumatic stress disorder. Ann Pharmacother, Vol.41, No.6, pp. 1917-1918.

Djavan, B.; Chapple, C. \& Milani, S. et al. (2004). State of the art on the efficacy and tolerability of alpha1 adrenoceptor antagonists in patients with lower urinary tract symptoms suggestive of benign prostatic hyperplasia. Urology, Vol.64, No.6, (December 2004), pp. 1081-1088.

Flach AJ. (2009). Intraoperative floppy iris syndrome: pathophysiology, prevention, and treatment. Trans Am Ophthalmol Soc, Vol.107, (December 2009), pp. 234-239.

Ford, RL.; Sallam, A. \& Towler, HM. (2011). Intraoperative floppy iris syndrome associated with risperidone intake. Eur Ophthalmol, Vol.21, No.22, (March-April 2011), pp. 210 211.

Herd, MK. Intraoperative floppy-iris syndrome with doxazosin (letter). (2007). J Cataract Refract Surg, Vol.33, No.4, (April 2007), p. 562.

Horvath, K. \& Vultur, F. (2011). Correlation between urological alpha1-AR antagonist medication and changed intraoperative iris behavior. Int Ophthalmol. Vol. 31, No. 2, (April 2011), pp. 99-104.

Issa, SA. \& Dagres, E. (2007). Intraoperative floppy-iris syndrome and finasteride intake. J Cataract Refract Surg, Vol.33, No.12, (December 2007), pp. 2142-2143.

Issa, S. Hadid, OH. \& Baylis, O.et al. (2008). Alpha antagonists and intraoperative floppy iris syndrome: A spectrum. Clinical Ophthalmology, Vol.2, No.4, (December 2008). pp. 735-741.

Kaplan, SA.; Roehrborn, CG. \& Rovner, ES. et al. (2006). Tolterodine and tamsulosin for treatment of men with lower urinary tract symptoms and overactive bladder: a randomized controlled trial. JAMA,Vol.296,No.19, (November 2006), pp. 2319-2328. 
Keklikci, U.; Isen, K. \& Unlu, K. et al. (2009). Incidence, clinical findings and management of intraoperative floppy iris syndrome associated with tamsulosin. Acta Ophthalmol. Vol. 87, No. 3, (May 2009), pp. 306-309.

Major cardiovascular events in hypertensive patients randomized to doxazosin vs chlorthalidone: the antihypertensive and lipid-lowering treatment to prevent heart attack trial (ALLHAT) ALLHAT collaborative research group. JAMA, (2000). Vol. 283, No.15, (April 2000), pp. 1967-1975.

Mc Vary, K. Roehrborn, C. \& Avins, A. et al. (2010). American Urological Association. Clinical Guideline: Management of benign prostatic hyperplasia (BPH). http://www.auanet.org/content/guidelines-and-quality-care/clinicalguidelines.cfm. Accessed March 25, 2011.

Marks, LS. Gittelman MC. \& Hill, LA. et al. (2009). Rapid efficacy of the highly selective alpha(1A) adrenoceptor antagonist silodosin in men with signs and symptoms of benign prostatic hyperplasia: pooled results of 2 phase 3studies. J Urol. Vol.181, No.6, (June 2009), pp. 2634-2640.

McNaughton-Collins, M. \& Barry, MJ. (2005). Managing patients with lower urinary tract symptoms. Am J Med, Vol. 118, No.12, (December 2005), pp. 1331-1339.

Navanimitkul, N. \& Lojanapiwat, B. (2010). Efficacy of tamsulosin $0.4 \mathrm{mg} /$ day in relieving double-J stent-related symptoms: a randomized controlled study. J Int Med Res, Vol.38, No 4, (July-August 2010), pp. 1436-1441.

Oetting, TA. (2009) Advances in the Management of Intraoperative Floppy Iris Sydnrome (IFIS). Refractive EyeCare. http://www.refractiveeyecare.com/articles/advances-inthe-management-of-intraoperative-floppy-iris-syndrome-ifis-301.html. Accessed March 26, 2011.

Oshika, T.; Ohashi, Y. \& Inamura M. et al. (2007). Incidence of intraoperative floppy iris syndrome in patients on either systemic or topical alpha(1)-adrenoceptor antagonist. Am J Ophthalmol. Vol.143, No.1, (January 2007), pp. 150-151.

Package insert. Flomax (tamsulosin hydrochloride). Ridgefield, CT: Boehringer Ingelheim, February 2007.

Palea, S.; Chang, DF. \& Rekik, M. et al. (2008). Comparative effect of alfuzosin and tamsulosin on the contractile response of isolated rabbit prostatic and iris dilator smooth muscles: possible model for intraoperative floppy-iris syndrome. J Cataract Refract Surg, Vol.34, No.3, (March 2008), pp. 489-496.

Panagis, L.; Basile, M. \& Friedman, AH. et al. (2010). Intraoperative floppy iris syndrome: report of a case and histopathologic analysis. Arch Ophthalmol, Vol.128, No.11 (November 2010), pp. 1437-1441.

Papadopoulos, R. \& Bachariou, A. (2007). Intraoperative floppy-iris syndrome associated with chronic intake of donepezil. J Cataract Refract Surg, Vol.33, No.11, (November 2007), pp. 1997-1998.

Product information. Rapaflo (silodosin). Corona, CA: Watson Pharmaceuticals, Inc., October 2008.

Raskind, MA.; Peskind, PR. \& Kanter, ED. et al. (2003). Reduction of nightmares and other PTSD symptoms in combat veterans by prazosin: a placebo-controlled study. Am J Psychiatry, Vol.160, No.2, (February 2003), pp. 371-373.

Roehrborn, CG.; for the ALFUS STUDY GROUP. (2001). Efficacy and safety of once-daily alfuzosin in the treatment of lower urinary tract symptoms and clinical benign 
prostatic hyperplasia: a randomized, placebo-controlled trial. Urology, Vol.58, No. 6, (December 2001), pp. 953-959.

Schwinn, DA. \& Afshari, NA. (2006). alpha(1)-Adrenergic receptor antagonists and the iris: new mechanistic insights into floppy iris syndrome. Surv Ophthalmol, Vol.51, No.5, (September-October 2006), pp. 501-512.

Settas, G. \& Fitt, AW. (2006). Intraoperative floppy iris syndrome in a patient taking alfuzosin for benign prostatic hypertrophy. Eye, Vol.20, No.12, (December 2006), pp. 1431-1432.

Shapiro, E.; Hartanto, V. \& Lepor, H. (1992). Quantifying the smooth muscle content of the prostate using double immuno-enzymatic staining and color assisted image analysis. J Urol, Vol.147, No.4, (April 1992), pp. 1167-1170.

Singh, A.; Alter, HJ. \& Littlepage, A. (2007). A systematic review of medical therapy to facilitate passage of ureteral calculi. Ann Emerg Med, Vol. 50, No. 5, (November 2007), pp. 552-563.

Srinivasan, S.; Radomski, S. \& Chung, J. et al. (2007). Intraoperative floppy-iris syndrome during cataract surgery in men using alpha-blockers for benign prostatic hypertrophy. J Cataract Refract Surg, Vol.33, No.10, (October 2007), pp. 1826-1827.

Suzuki, F.; Taniguchi, T. \& Nakamura, S. et al. (2002). Distribution of alpha-1 adrenoceptor subtypes in RNA and protein in rabbit eyes. Br J Pharmacol, Vol.135, No.3, (February 2002), pp. 600-608.

Takmaz, T. \& Can, I. (2007). Clinical features, complications, and incidence of intraoperative floppy iris syndrome in patients taking tamsulosin. Eur J Ophthalmol, Vol. 17, No.6, (November-December 2007), pp. 909-913.

Thiyagarajan, M. (2002). a-Adrenoceptor antagonists in the treatment of benign prostate hyperplasia. Pharmacology, Vol.65, No.3, (July 2002), pp. 119-128.

Unal, M.; Yucel, I. \& Tenlik, A. (2007). Intraoperative floppy-iris syndrome associated with chronic use of chlorpromazine. Eye, Vol.21, No.9, (September 2007), pp. 1241-1242.

Venkatesh R.; Veena, K. \& Gupta, S. et al. (2007). Intraoperative floppy iris syndrome associated with terazosin. Indian J Ophthalmol, Vol.55 No.5, (September-October 2007), pp. 395-396.

Yeu, E. \& Grostern, R. (2007). Saw palmetto and intraoperative floppy-iris syndrome. J Cataract Refract Surg, Vol.33,No.5, (May 2007), pp. 927-928.

$\mathrm{Yu}, \mathrm{Y}$. \& Koss, MC. (2003). Studies of alpha adrenoceptor antagonists on sympathetic mydriasis in rabbits. J Ocul Pharmacol Ther, Vol.19, No.3, (June 2003), pp. 255-263. 